\title{
Pilot Study of Food Consumption Pattern: Assessment of validity of dietary history method
}

\author{
Susilowati Herman", Yoshiyuki Ohno ${ }^{\dagger}$, Drupadi Dillon ${ }^{\ddagger}$, Santoso Cornain ${ }^{\S, \neq}$, , Goi Sakamoto II, \\ Idral Darwis", Kenji Wakai ${ }^{\dagger}$, Joedo Prihartono $^{* *}$, Susumu Watanabe ${ }^{\dagger \dagger}$, Esti Sutrisno ${ }^{\S}$, Muchlis Ramli", \\ Setyawati Budiningsih $^{* *}$, Sadao Suzuki ${ }^{\dagger}$, Endang Sri Roostini ${ }^{\S}$, Didid Tjindarbumi ${ }^{\top}$, Gunawan Tjahjadi ${ }^{\S}$
}

\begin{abstract}
Abstrak
Validitas relatif pola konsumsi makanan yang diukur dengan Dietary History Method dibandingkan dengan pola konsumsi yang sebenarnya yang diukur 6-8 minggu sebelumnya dengan cara penimbangan dan pencatatan selama 7 hari. Sejumlah 20 ibu usia 24-56 tahun dicakup dalam penelitian ini. Tingkat pendidikan subyek bervariasi dari SMTP sampai tingkat akademi. Hasil penelitian ini menunujukkan bahwa: i) $25 \%$ (5/20) responden tidak dapat mengingat frekwensi konsumsi lemak hewani; ii) 90\% (18/20) responden dapat mengingat dengan baik frekuensi konsumsi lemak nabait, terutama minyak kelapa. iii) hampir $90 \%$ responden dapat mengingat frekwensi konsumsi gula merah dan roti, dan sekitar 50\% respanden gagal mengingat frekuensi konsumsi ubi dan mi; iv) sekitar $60-80 \%$ responden berhasil mengingat frekuensi konsumsi bahan makanan sumber protein hewani seperti daging sapi, jerohan, ayam, ikan, telur, dan susu, tetapi gagal mengingat frekuensi konsumsi makanan hewani lainnya seperti daging kambing, udang, korned, dan ikan asin; v) hampir seluruh responden (95\%) dapat mengingat dengan baik frekuensi konsumsi sayur daun hijau seperti bayam, kangkung, daun singkong, daun katu, dan wortel; vi) $80 \%$ responden tidak dapat menyebutkan frekuensi konsumsi sayuran lainnya seperti ketimun taoge, dll; vii) seluruh responden cenderung menyatakan lebih (Overestimate) untuk frekuensi konsumsi buah-buahan. Secara umum, responden dapat mengingat dengan baik frekuensi konsumsi makanan yang dikonsumsi secara teratur dan sering. Sementara untuk makanan yang jarang dikonsumsi (dua minggu sekali atau kurang), sulit diingat frekuensi konsumsinya.
\end{abstract}

\begin{abstract}
The relative validity of dietary history method was assessed against the actual dietary intake using 7 days precise weighing method performed 6-8 weeks previously. A total of 20 women, aged 24 to 56 years, parlicipated in this pilot study. Their education level were junior and senior high school. The 7 days precise weighing method and dietary history was done by assistant nutritionist. The results of this pilot study showed that: i) 5/20 (25\%) respondents could not remember the frequency of the animal fat consumed; ii) 18/20 (90 $\%$ ) respondents had quite good memorization close to the actual food pattern of vegetable fat, especially for coconut oi; iii) almost $90 \%$ of the respondents could memorize the frequency of using cane sugar and bread, while almost $50 \%$ of respondents failed to memorize the potato and noodles; iv) 14-16 (60-80\%) respondents could remember the frequency of using beef, intestinal organs, chicken, fish, egg, and milk closed to the actual food pattern; v) most of the respondents (95\%) were able to recall the frequency of consuming the green leafy vegetables as spinach, swamp cabbage, cassava leaves, katu leaves, and carrots; vi) 80\% of the respondents did not have a good recall of consuming other vegetables as cucumber, sprout, etc; vii) all respondents tend to overestimate the frequency of fruits. In general, it appeared that respondents could memorize their food consumption pattern, especially for food which was frequently and regularly consumed, while they tend to overestimate the food frequency of rarely consumed food.
\end{abstract}

Keywords: nutritional study, food consumption pattern, breast cancer

* Research and Development Center for Nutrition, Bogor, Indonesia

${ }^{\dagger}$ Department of Preventive Medicine, Nagoya University, School of Medicine, Nagoya 466, Japan

$¥$ Department of Nutrition, Faculty of Medicine, University of Indonesia, Jakarta 10430, Indonesia

$\S$ Department of Anatomic Pathology, Facully of Medicine, University of Indonesia, Jakarta 10430, Indonesia

II Department of Pathology, Cancer Institute, Tokyo 170, Japan

Department of Surgery, Faculty of Medicine, University of Indonesia, and Dr. Cipto Mangunkusumo National Central General Hospital, Jakarta 10430, Indontesia

* Department of Community Medicine, Faculty of Mediciue, University of Indonesia, Jakarta 10320, Indonesia

${ }^{+t}$ Department of Surgery, Cancer Institute, Tokyo 170, Japan

${ }^{\ddagger}$ Research Center for Medical Science and Technology, Faculty of Medicine, University of Indonesia, Jakarta 10430, Indonesia
So far, there have been no gold standard in the assessment of individual dietary intake methodology. ${ }^{1}$ The choice of dietary intake method to estimate individual food intake depends on the objectives for the assessment of individual intake. 1,2 Most of the available methods were aimed at assessing current food consumption. In epidemiologic studies examining the relationship between nutrition and the risk of non communicable diseases such as cancer, coronary heart disease, hypertension, various methods have been used to assess dietary intake and dietary pattern. ${ }^{3,4}$ Correlation study, cohort study and case-control study for dietary factor evaluation in cancer have been applied in Japan and the results have been reviewed by one of us. 
Apparently, the analysis of case-control study on the significance of fat consumption as risk factor in breast cancer in Japan has been still unclear. Similar finding in the neighbouring population has been reported. ${ }^{6}$

Since our data showed that fatty food consumption was significant risk factor in breast cancer of the Indonesian females, ${ }^{7,8}$ the collaborative study has been extended with further nutritional analysis. Basically, the case-control study was designed but some improvements in the assessment of food consumption and its micronutrient analysis have been proposed.

Therefore, we consider that assessing the food consumption pattern of a person at some period in the past is the proper choice rather than actual intake at the present time.

In this paper, the results of a pilot study of food consumption patten of adult women as part of preliminary set up of nutritional study in breast cancer will be presented.

The purpose of this study were to compare the food consumption pattern analyzed by food frequency method with the actual food pattern.

\section{METHODS}

A total of 20 women were recruited in this pilot study. The characteristics of the subject of the pilot study were as follows: 1 ). The age of the subjects were 24-56 years old; 2). The education level varied from junior high school up to college. Special questionnaire were designed, emphasizing the inclusion of the unique Indonesian food items.

The data of seven days actual food intake were collected using precise weighing method by assistant nutritionist. The study was conducted in March till May 1992. The food frequency pattern in terms of frequency per week and the amount of this method was validated by comparison with dietary history data of 6-8 weeks after weighing by nutritionist. Comparisons were made for food items and its frequency per week and amount obtained by these two methods. Number of respondents who stated the same food items and its frequency and amount obtained by these two methods were categorized as matched.

\section{RESULTS}

The comparison of the food patterns obtained by the two methods were as follows. See also details given in Table 1.

\section{Animal fat}

From 6 food items (chicken fat, beef fat, lamb fat, pork, and butter) 5 out of 20 respondents could not memorize the frequency of the food items used.

\section{Vegetable fat}

From 4 food items (coconut oil, coconut milk, coconut, and margarine), 18 out of 20 respondents gave quite good memorizing closed to the actual food pattern, especially for coconut oil. The frequency of using coconut milk and coconut were interchangeable.

\section{Source of carbohydrate}

From 9 food items included in this questionnaire, most of the respondents could memorize the frequency of consuming cane sugar and bread. Only 3 respondents did not remember the frequency of using these kinds of foods. Almost $50 \%$ of the respondents failed to memorize the frequency of potato and noodles; while most of the respondents could not memorize the rest. Rice was not included in this questionnaires.

\section{Animal protein}

From 15 kinds of animal protein food, 14-16 respondents could memorize the frequency of consuming beef, intestinal organs, chicken, fish, egg, and milk closed to the actual food pattern. As to the other foods such as lambs, prawn, corned beef, salted fish, etc. most of the respondents failed to memorize the frequency.

\section{Vegetables}

For the green leafy vegetables such as spinach, swamp cabbage, cassava leaves, katu leaves, carrots, most of the respondents gave a good memorizing of the frequency of using these kinds of foods. While for other vegetables such as cucumber, sprout, etc, the respondents did not give a good memorizing.

\section{Fruits}

It appeared that in 6-8 weeks food pattern analysis the respondents tend to overestimate their consumption as compared to the actual food pattern.

Juice, cola, and 18 kinds of snacks

As to the use of fruits the respondents tend to overestimate the frequency of using snacks in 6-8 weeks food pattern analysis as compared to the actual food pattern.

\section{DISCUSSION}

In general, most subjects could memorize their food consumption pattern, especially for the food which was 
Table 1. Comparison of food frequency assessed by the seven days precise weighing method and a dietary history method 6-8 weeks later.

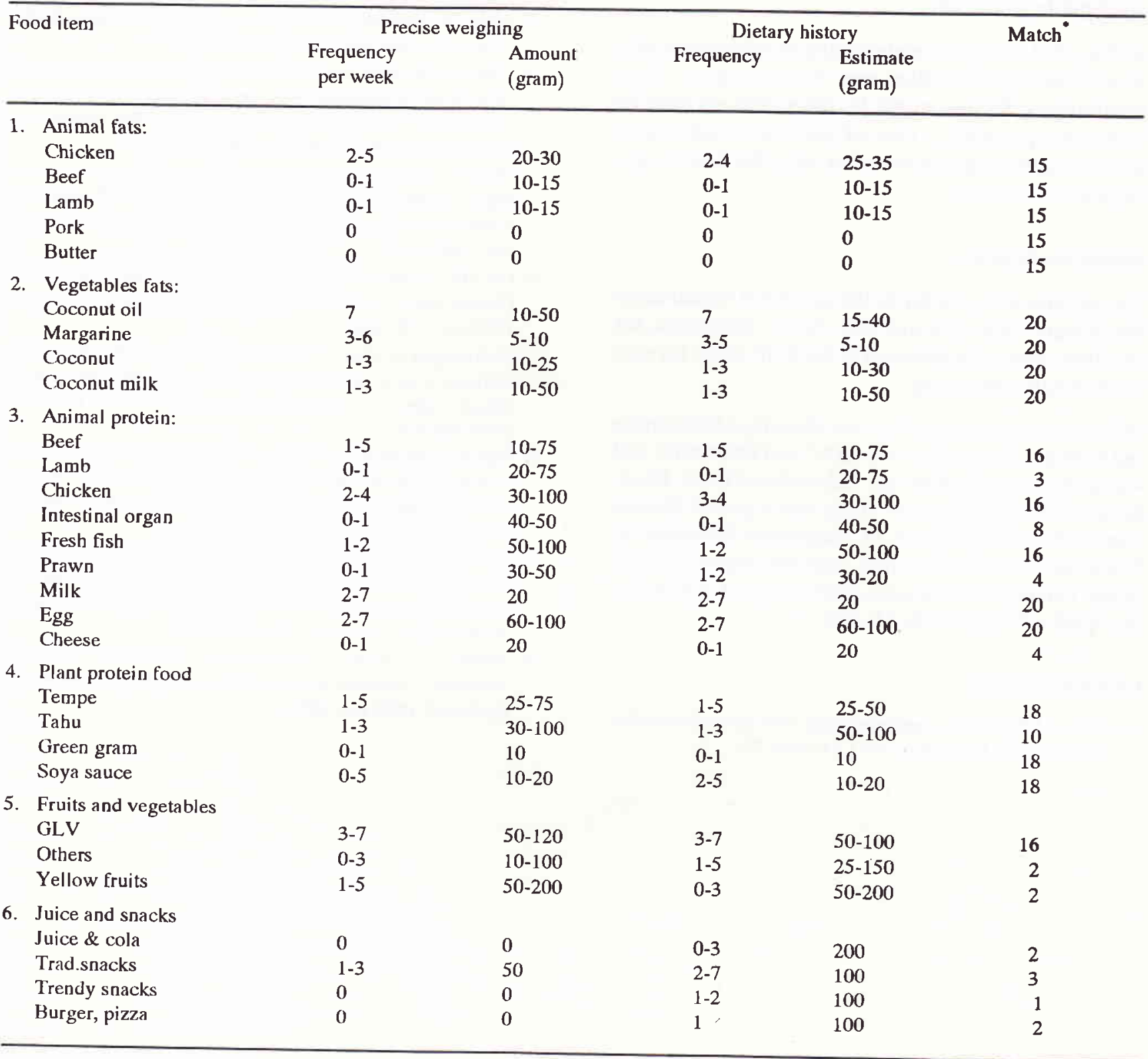

\footnotetext{
*) Number of respondent who stated the same food items and its frequency and amount of these two methods were categorized as
matched.
}

frequently and regularly consumed such as chicken, beef, lamb, coconut oil, coconut, coconut milk, tempe, green gram, soya sauce, green leafy vegetables. Food which was consumed less than once per week or on monthly basis, was hard to be memorized by the subject. For this kind of food most of the subject tend to overestimate. Their consumption Anderson et al ${ }^{9}$ in their studies found that self-administered quantitative food frequency questionnaire is useful for measuring individual intake. Dwyer et al ${ }^{10}$ in their study concluded that recall of food intake in the distant past may be a sufficiently valid estimate of past intake. Other researcher found that retrospectively collected dietary data have some significance, although question 
remains whether the retrospective dietary history method will be sufficiently valid for use in a particular epidemiological study. ${ }^{4}$

In this pilot study, the memorizing of subjects on their food consumption pattern was relatively good. Some confounding factors might be taken into account for better interpretation. One of potential confounding factors might be special occasion when the food weighing was performed.

\section{Acknowledgments}

The authors are grateful to the asssistant nutritionists Ms. Emma Suhaedah and Ms. Juniar Rosmalina for excellent data collection and to the EDP staffs for nice work in data processing.

This work was supported by the Ministry of Education and Culture, Grants No. 01042007 and 04042013; and was partly supported by the Indonesian Cancer Foundation. This collaborative study was a part of Special Cancer Research Project in Monbusho International Scientific Research Program, with the approval of the Dean, Faculty of Medicine, University of Indonesia, No. 4383 / PT02.H4.FK / E / 88.

\section{REFERENCES:}

1. Connor EB, Nutrition epidemiology: how do we know what they eat. Am J Clin Nutr 1991;54:182S-7S.
2. Hsu-Hage BHH, Wahlquist ML. A food questionnaire for use in Chinese populations and its validation. Asia Pacific J Clin Nutr 1992;1:211-21.

3. Marr JW. Individual dietary surveys: purposes and methods. Worls Rev Nutr Diet 1971;13:105-64.

4. Van Leeuwen FE, De Vet HCW, Hayes RB, Van Staveren WA, West C, Hautvast GAJ. An assessment of the relative validity of retrospective interviewing for measuring dietary intake. Am J Epideiol 1983;118:752-8.

5. Ohno Y. Methodology and evaluation of dietary factors in Japan. In: Mettline CJ, Aoki K, editors. Recent Progress in Research on Nutrition and Cancer. New York: Wiley-Liss Inc. 1990;11-20.

6. Lee HP, Gourley L, Duffy SW, Esteve J, Lee J, Day NE. Dietary effects on breast-cancer risk in Singapore. Lancet 1991;337:1197-200.

7. Budiningsih S, Ohno Y, Prihartono J, Ramli M, Wakai K, Cornain S, et al. Epidemiological analysis of risk factors breast cancer in Indonesia females. Med J Indones 1995;4:163-8

8. Suzuki S, Prihartono J, Ohno Y, Budiningsih S, Wakai K, Cornain S, et al. Epidemiological risk factors for breast cancer related to menopausal status in Indonesia. Med J Indon 1995; 4:169-76.

9. Anderson MNLF, Solvoll K, Standstad B, Hustvedt BE, Lovo A, Drevon CA. Accuracy of a quantitative applied food frequency questionnaire applied in elderly Norwegian women. Eur J Clin Nutr 1992;46:809-21.

10. Dwyer YT, Gardner J, Halvorsen K, Krall EA, Cohen A, Valadian I. Memory of food intake in the distant past Am J Epidemiol 1989;130:1023-46. 